\title{
Studies on the susceptibility of the mouse preimplantation embryo to infection with cytomegalovirus
}

\author{
P. A. Neighbour* \\ Clinical Research Centre, Watford Road, Harrow, Middlesex, HAl 3UJ, U.K.
}

\begin{abstract}
Summary. Intact and zona-free mouse preimplantation embryos were exposed to murine cytomegalovirus in vitro at various stages of development. The embryos developed normally to the blastocyst stage, and there was no evidence of embryonic infection. Intraperitoneal inoculation of female mice with this virus produced an acute generalized infection, and embryonic development was retarded in vivo. The embryos themselves were not productively infected, and they developed into apparently normal fetuses when transferred to uninfected mice.
\end{abstract}

\section{Introduction}

Acute maternal infection with murine cytomegalovirus (MCMV) causes developmental retardation of the mouse preimplantation embryo (Neighbour, 1976). This failure could be due to direct infection of the embryos with the virus or to indirect consequences of maternal disease. A direct interaction between viruses and the preimplantation embryo could affect subsequent development. For example, A- and C-type oncovirus particles, identical to those found in certain neoplastic tissues, have been found in oocytes and preimplantation embryos of mice (Chase \& Pikó, 1973), guinea-pigs (Enders \& Schlafke, 1965; Andersen \& Jeppesen, 1972) and primates (Kalter et al., 1974a, b), and their presence may be related to the development of neoplasia in later life (Biczysko, Pienkowski, Solter \& Koprowski, 1973a). The viruses which cause murine leukaemia and mammary tumours in certain mouse strains are known to be transmitted vertically via the egg and early embryo (Zeilmaker, 1969; Bentvelzen, Daams, Hageman \& Calafat, 1970; Gross, 1970). Similarly, it has been postulated that infection of the ovum and early embryo with lymphocytic choriomeningitis virus may be the route of transmission of this virus from parent to progeny (Mims, 1966). Experimental studies in vitro have shown that mouse preimplantation embryos are permissive hosts for the replication of several viruses and that embryonic infection usually causes abnormal development and embryonic death (Gwatkin \& Auerbach, 1966; Sawicki, Baranska \& Koprowski, 1971; Chase, Winters \& Pikó, 1972; Biczysko, Solter, Pienkowski \& Koprowski, 1973b; Mohanty \& Bachmann, 1974).

In the present study, mouse embryos were exposed to murine cytomegalovirus in vitro or in vivo to determine whether the preimplantation stages were susceptible to productive infection by this virus.

\section{Materials and Methods}

Virus

The Smith strain of murine cytomegalovirus (Smith, 1954) was used throughout. Virus for embryo treatment in vitro was obtained by a single low multiplicity passage ( $<1$ PFU per cell) of infected salivary gland homogenate in monolayers of mouse embryo fibroblasts derived from Day-15 fetuses and cultured in Eagle's Minimum Essential Medium (MEM) containing 5\% (v/v) fetal calf serum (FCS). The supernatant virus was harvested after $72 \mathrm{~h}$ and centrifuged at $3000 \mathrm{~g}$ for $10 \mathrm{~min}$ at $4^{\circ} \mathrm{C}$ to remove cell debris. The supernatant from monolayers of uninfected mouse embryo fibroblasts was harvested for use as a control. Virus for intraperitoneal (i.p.) inoculation was as reported previously

\footnotetext{
* Present address: Albert Einstein College of Medicine, Department of Microbiology and Immunology, Bronx, New York 10461, U.S.A.
} 
(Neighbour, 1976). Control inocula were prepared by heating virus stocks at $56^{\circ} \mathrm{C}$ for $30 \mathrm{~min}$ and were found to be free of infectious virus on mouse embryo fibroblasts. All virus titrations were performed on fibroblast indicator cells, by using a semimicro plaque assay (Rager-Zisman \& Merigan, 1973), and are expressed in plaque forming units (PFU).

\section{Collection and treatment of embryos in vitro}

Virgin female BALB/c mice, 6-8 weeks old, were induced to ovulate by i.p. injections of 2 i.u. PMSG (Gestyl: Organon) and 2 i.u. hCG (Pregnyl: Organon) $48 \mathrm{~h}$ later. After the second injection the mice were paired with mature, fertile male BALB/c mice, and overnight mating was detected by the presence of a vaginal plug. At $46 \mathrm{~h}$ after $\mathrm{hCG}, 2$-cell embryos were flushed from the oviducts of mated mice with Whittingham's medium based on Tyrode's solution (Whittingham, 1971). This medium was used throughout for all embryo manipulations and culture. The embryos from several mice were pooled and transferred to $50 \mu$ d droplets of medium under paraffin oil in plastic dishes (Falcon Plastics). The embryos were incubated at $37^{\circ} \mathrm{C}$ in a water-saturated atmosphere of $5 \% \mathrm{CO}_{2}$ in air for 2, 24 or $48 \mathrm{~h}$ so that they were at the 2-cell, 8-cell or compact morula stage respectively for treatment with the virus. Zona pellucidas were removed by digestion in pronase (Mintz, 1962) from some embryos. This was done at least $2 \mathrm{~h}$ before treatment to allow for membrane recovery. For treatment, embryos of the required stage were randomly divided into subgroups of 12 embryos and transferred to $50 \mu \mathrm{l}$ droplets of culture medium containing $5 \mu \mathrm{l}$ virus ( $3500 \mathrm{PFU}$ ) or control medium. Each treatment group contained 10 or 12 replicate subgroups. After incubation for $2 \mathrm{~h}$, the embryos were rinsed by passing them through 3 droplets of fresh medium. After transfer to the final droplet of culture medium, the embryos were incubated as described above for $72 \mathrm{~h}$ (2-cell) or $48 \mathrm{~h}$ (8-cell and morula) and were then examined under a stereomicroscope. The number of apparently normal blastocysts in each group was determined, and this quantal response was compared between groups by a 2-factor analysis of variance without replication (Snedecor \& Cochran, 1967) on the angular transformed values (Claringbold, Biggers \& Emmens, 1953).

\section{Infection of mice and treatment of embryos in vivo}

Mice were inoculated i.p. with infections or heat-inactivated MCMV as described elsewhere (Neighbour, 1976), either 7 days before or 1 day after mating with uninfected males, to produce an acute generalized infection during the preimplantation period of pregnancy. Some of the inoculated mice were killed every day: the submaxillary glands, blood, genital tracts and embryos were examined for the presence of MCMV.

Embryos were obtained from the other mice on Day 4 of pregnancy by flushing the uteri with embryo culture medium. Morphologically normal expanded blastocysts were selected from a pool of embryos, and 6 were transferred non-surgically by the technique of Marsk \& Larsson (1974) into each uterine horn of uninfected pseudopregnant CBA mice, mated 3 days previously with vasectomized CBA males. The recipients were killed on Day 18 of pregnancy, and their uteri were examined for implantations. In addition, the fetuses and their placentas were removed from the membranes, blotted dry and weighed. These data were analysed statistically by the application of $\chi^{2}$ tests or the single-factor analysis of variance (Snedecor \& Cochran, 1967), and significance was accepted throughout at the $5 \%$ level.

\section{Detection of infectious virus in embryos and tissues}

Groups of embryos were rinsed 3 times in sterile phosphate-buffered saline (PBS) and cocultivated in monolayers of mouse embryo fibroblasts or suspended in $1 \mathrm{ml} \mathrm{MEM}$ containing $5 \%$ (v/v) FCS, rapidly frozen and thawed to disrupt the blastomeres and titrated as described above. Droplets of embryo culture medium were suspended in $1 \mathrm{ml}$ of the same medium and similarly titrated.

Whole blood was collected from each mouse by cardiac puncture and diluted with an equal volume of PBS containing 10 i.u. heparin. Both uterine horns, with attached ovaries and oviducts, were excised, freed of mesentery and adipose tissue, blotted dry and rinsed 3 times in sterile PBS to 
remove any contaminating blood. They were homogenized with a ground-glass homogenizer in $1 \mathrm{ml}$ MEM containing $5 \%(\mathrm{v} / \mathrm{v}) \mathrm{FCS}$. All tissue samples were rapidly frozen to $-70^{\circ} \mathrm{C}$ and stored until titrated as above.

\section{Immunofluorescent detection of viral antigen in embryos and tissues}

Embryos were air-dried onto clean glass coverslips, fixed with cold $\left(4^{\circ} \mathrm{C}\right)$ acetone and rinsed 3 times with PBS. Genital tracts were snap-frozen in cold (approx. $-75^{\circ} \mathrm{C}$ ) isopentane, cryostatsectioned at $6 \mu \mathrm{m}$ and mounted onto glass slides. Sections were air-dried and fixed with cold $\left(4^{\circ} \mathrm{C}\right)$ acetone before staining, or processed without prior fixation. Embryos and tissue sections were stained by the indirect technique using anti-MCMV serum and FITC-conjugated rabbit antiserum to mouse IgG (Sera Services) containing 10\% (v/v) rhodamine-labelled bovine serum albumin (Becton, Dickinson \& Co.) as counterstain. All sera were absorbed before use with equal weights of acetone-dried mouse liver powder slaked with PBS. In addition, for staining of genital tract sections, the sera were absorbed with homogenized uninfected genital tracts to prevent non-specific fluorescence. Stained preparations were examined microscopically with ultraviolet illumination.

\section{Embryo ultrastructure}

Embryos were rinsed thoroughly with PBS, fixed in $2.5 \%(\mathrm{v} / \mathrm{v})$ glutaraldehyde in $2.1 \%(\mathrm{v} / \mathrm{v})$ sodium cacodylate buffer and post-fixed in $1 \%(\mathrm{w} / \mathrm{v})$ osmium tetroxide. Araldite blocks were sectioned at $90 \mathrm{~nm}$ and stained with lead citrate and uranyl acetate before viewing on a Siemens Elmiskop 1.

\section{Results}

\section{In vitro}

The exposure of intact and zona-free embryos to MCMV did not impair development to the blastocyst stage (Table 1): no infectious virus was detected in any of the embryos or their culture media; no MCMV-specific fluorescence and no MCMV-like particles were observed in any of the embryos. These results show that the preimplantation embryos did not become productively infected when exposed to MCMV in vitro.

Table 1. Development of mouse preimplantation embryos after exposure to cytomegalovirus in vitro

\begin{tabular}{|c|c|c|c|c|}
\hline $\begin{array}{l}\text { Stage of embryo } \\
\text { at treatment }\end{array}$ & $\begin{array}{l}\text { Treatment } \\
\text { group }\end{array}$ & $\begin{array}{l}\text { No. of } \\
\text { replicate } \\
\text { subgroups }\end{array}$ & $\begin{array}{c}\text { Response* } \\
(\text { mean } \pm \text { s.e.m. })\end{array}$ & $\begin{array}{c}\text { Variance } \\
\text { ratiof } \\
\text { between groups }\end{array}$ \\
\hline Intact 2-cell & $\begin{array}{l}\text { Control } \\
\text { Virus }\end{array}$ & $\begin{array}{l}10 \\
10\end{array}$ & $\begin{array}{l}6 \cdot 5 \pm 0.3 \\
6 \cdot 3 \pm 0.3\end{array}$ & 0.32 \\
\hline Intact 8-cell & $\begin{array}{l}\text { Control } \\
\text { Virus }\end{array}$ & $\begin{array}{l}12 \\
12\end{array}$ & $\begin{array}{l}7 \cdot 1 \pm 0.7 \\
7.2 \pm 0.6\end{array}$ & $0 \cdot 10$ \\
\hline Intact morula & $\begin{array}{l}\text { Control } \\
\text { Virus }\end{array}$ & $\begin{array}{l}12 \\
12\end{array}$ & $\begin{array}{l}8 \cdot 2 \pm 0.5 \\
7 \cdot 8 \pm 0.5\end{array}$ & 0.29 \\
\hline Zona-free 2-cell & $\begin{array}{l}\text { Control } \\
\text { Virus }\end{array}$ & $\begin{array}{l}10 \\
10\end{array}$ & $\begin{array}{l}3.1 \pm 0.4 \\
2.8 \pm 0.4\end{array}$ & 0.35 \\
\hline Zona-free 8-cell & $\begin{array}{l}\text { Control } \\
\text { Virus }\end{array}$ & $\begin{array}{l}10 \\
10\end{array}$ & $\begin{array}{l}8.2 \pm 0.4 \\
7 \cdot 7 \pm 0.3\end{array}$ & $2 \cdot 81$ \\
\hline Zona-free morula & $\begin{array}{l}\text { Control } \\
\text { Virus }\end{array}$ & $\begin{array}{l}10 \\
10\end{array}$ & $\begin{array}{l}9.6 \pm 0.3 \\
9.0 \pm 0.3\end{array}$ & $2 \cdot 77$ \\
\hline
\end{tabular}

* The no. of morphologically normal blastocysts developed from 12 embryos per subgroup after culture.

† Variance ratios calculated from the 2 -factor analysis of variance without replication on the response values after angular transformation. 


\section{In vivo}

Infected mice exhibited ruffling of fur, weight loss, shivering and reduced activity between 3 and 7 days after inoculation. Eosinophilic intranuclear inclusion bodies and cytomegaly of the acinar cells, together with infiltration of mononuclear cells around the acini, were observed histologically in the submaxillary glands by 7 days after inoculation. These pathological changes are characteristic of acute generalized MCMV infection. Inflammation of the genital tract occurred in $60 \%$ of the infected mice by 3 days after inoculation. In some mice, there was marked necrosis of the uterine epithelia and lymphocytic infiltration around uterine crypts. No pathological changes or signs of disease were found in any of the mice injected with heat-inactivated virus. Infectious virus was isolated in the blood of infected mice between 3 and 7 days, and in genital tract homogenates between 4 and 6 days, after inoculation. No MCMV-specific antigen was detected in uterine, oviductal or ovarian tissues of infected mice examined daily throughout the period of generalized infection.

As in the previous study (Neighbour, 1976), embryos derived from acutely infected mice on Day 4 of pregnancy were developmentally retarded: there were fewer blastocysts and more morulae and degenerate embryos than in uninfected control mice (data not shown). When groups of embryos from infected mothers were co-cultivated with fibroblasts, no characteristic MCMV-induced cytopathology was observed at any time during the 3 successive subcultures. No MCMV-specific fluorescence was observed in any of the embryos obtained from infected or uninfected mice on Days 2, 3 and 4 of pregnancy, but several virus-like particles were seen in a few blastomeres of embryos recovered on Day 4 of pregnancy from infected mice. The particles were budding from the nuclear membrane or contained in cytoplasmic vesicles: they were distinct from the endogenous A- and C-type particles found in mouse preimplantation embryos (Chase \& Pikó, 1973) and were of similar size and morphology to the intracellular MCMV particles observed in MCMV-infected hepatic parenchymal cells (Reubner, Miyai, Slusser, Wedemeyer \& Medearis, 1964). However, none of the embryonic blastomeres examined exhibited the acute productive infection typical of MCMVinfected somatic cells.

The results of the embryo transfer experiment are shown in Table 2. No significant differences were observed in the preimplantation loss, pregnancy rate, implantation rate, litter size or fetal and placental weights in recipients of embryos derived from either infected or uninfected donors, and all viable fetuses appeared morphologically normal. No MCMV-specific fluorescence was observed in any of the fetal tissues examined.

Table 2. Implantation of embryos derived from donors inoculated i.p. with cytomegalovirus after transfer to the uteri of uninfected recipient mice

\begin{tabular}{|c|c|c|c|c|c|c|c|c|}
\hline \multirow{3}{*}{$\begin{array}{c}\text { Donor } \\
\text { treatment } \\
\text { group }\end{array}$} & \multirow{3}{*}{$\begin{array}{c}\text { Pre- } \\
\text { implantation } \\
\text { loss* }(\%)\end{array}$} & \multirow{3}{*}{$\begin{array}{l}\text { Pregnancy } \\
\text { rate† }(\%)\end{array}$} & \multicolumn{6}{|c|}{ Recipients at Day 18 of pregnancy } \\
\hline & & & \multirow{2}{*}{$\begin{array}{c}\text { Implantation } \\
\text { rate } \neq(\%)\end{array}$} & \multicolumn{3}{|c|}{ Implantations } & \multicolumn{2}{|c|}{ Mean wt (mg) } \\
\hline & & & & Live & Dead & Total & Fetus & Placenta \\
\hline Uninfected & $177 / 216(82)$ & $9 / 18(50)$ & $39 / 108(36)$ & $1.7 \pm 0.4$ & $2 \cdot 7 \pm 0.5$ & $4 \cdot 3 \pm 0 \cdot 8$ & $791 \pm 31$ & $121 \pm 12$ \\
\hline Infected & $161 / 240(79)$ & $12 / 20(60)$ & $51 / 144(35)$ & $1 \cdot 7 \pm 0 \cdot 3$ & $2 \cdot 6 \pm 0.4$ & $4.3 \pm 0.5$ & $878 \pm 39$ & $124 \pm 17$ \\
\hline
\end{tabular}

Values are mean \pm s.e.m.

* [(Total no. of blastocysts transferred - total no. of implantations)/total no. of blastocysts transferred] $\times 100$.

$\dagger[$ Total no. of pregnant mice/total no. of recipients] $\times 100$.

$\ddagger$ [Total no. of implantations/total no. of blastocysts transferred (pregnant recipients only)] $\times 100$.

\section{Discussion}

While a number of studies have found that mouse preimplantation embryos are permissive hosts for several diverse and unrelated viruses, the experiments reported here show that mouse embryos are 
not susceptible to productive infection with MCMV in vitro or in vivo. The reasons for this nonsusceptibility are not entirely clear, but the block must have occurred before or early in the replication cycle because no viral proteins were detected in virus-treated embryos by immunofluorescence. A lack of receptors for virus adsorption and penetration, an inability of the virus to uncoat, or a blockage in viral genome expression could each be responsible for the failure of MCMV to infect these embryonic cells. The 2-cell mouse embryo is known to lack receptors for polyoma virus attachment, whereas by the blastocyst stage this virus can adsorb to and penetrate the embryonic cell membrane (Biczysko et al., 1973b). If the block in virus replication was in transcription or translation of the viral genome, the techniques used in this study would not have detected this latent infection. However, DNA-hybridization could be used to detect viral genome or RNA transcripts in treated embryos.

Cells derived from the embryonic portion (egg cylinder), but not from the trophoblast (ectoplacental cone), of the 8-day embryo will support the replication of MCMV in vitro (Neighbour, 1977), and so susceptibility to this virus must be acquired by the embryo sometime before Day 8 of pregnancy. Because the susceptible cells of the 8-day embryo are derived from the blastocyst inner cell mass (ICM) (Gardner \& Papaioannou, 1975), the differentiation of the preimplantation embryo into ICM and trophoblast at the late morula stage might be accompanied by the development of susceptibility to MCMV. The blastomeres of the pre-morula stages are non-permissive, and after blastocyst formation, the non-permissive trophoblast might prevent infectious virus from reaching the ICM, and hence protect the embryo from infection with this virus. Experiments are in progress to determine whether MCMV can productively infect the ICM itself.

The zona pellucida is impermeable to simian virus 40 (Sawicki et al., 1971) and to the minute virus of mice (Mohanty \& Bachmann, 1974), but Gwatkin (1967) has demonstrated the rapid passage of Mengovirus through this embryonic investment. In the present experiments, impermeability of the zona to MCMV cannot alone explain the failure to infect the early embryo because zona-free embryos also escaped infection.

The failure to infect early mouse embryos with MCMV in vitro and in vivo strongly suggests that the developmental retardation observed in embryos from acutely infected mice was caused by indirect, rather than direct, interaction between virus and embryo. In addition, although some pathological changes did occur in uterine tissues, there was little evidence of acute uterine infection. Immunofluorescent staining was negative, and the low titres of virus detected in genital tracts during the viraemia were probably attributable to the presence of blood in the tissue homogenates. Inoculation 7 days before mating also caused abnormal development (Neighbour, 1976) even though the acute maternal infection and viraemia had subsided before preimplantation development began. It is unlikely, therefore, that the developing embryos would have encountered MCMV in utero. The uterine pathology in infected mice may have resulted from hormonal imbalance induced by the acute infection, which in turn may have adversely affected embryonic development. Neighbour (1977) has shown that acute, localized MCMV infection of the uterus, induced by intrauterine inoculation of the virus on the day of mating, also retarded preimplantation development without causing productive embryonic infection.

The observation of a few MCMV-like particles in embryos derived from infected mice is difficult to interpret, since all other techniques used here failed to detect any embryonic infection. Ultrastructural examination did not indicate productive infection and the cells which contained these particles appeared to be morphologically normal. If these particles were indeed MCMV, then they were probably parental rather than progeny virions. It is possible that at a later stage of development they might undergo replication, but the embryo transfer experiment did not produce any evidence for this because all the derived fetuses were normal and uninfected. However, the transfer technique, which necessitates the selection of apparently healthy blastocysts for successful transfer, probably excluded any potentially abnormal embryos.

I thank Dr D. A. J. Tyrrell, Dr L. R. Fraser and Dr R. D. Barnes for their constructive advice; Mrs R. J. Tilly for the electron microscopy; and Kathy Brown and Linda Drury for their excellent technical assistance. The work was carried out during the tenure of a Medical Research Council Studentship. 


\section{References}

Andersen, A.A. \& Jeppesen, T. (1972) Virus-like particles in guinea pig oogonia and oocytes. J. natn. Cancer Inst. 49, 1403-1410.

Bentvelzen, P., DaAms, J.H., Hageman, P. \& Calafat, J. (1970) Genetic transmission of viruses that incite mammary tumor in mice. Proc. natn. Acad. Sci. U.S. 4. 67, 377-384.

Biczysko, W., Pienkowski, M., Solter, D. \& KopRowski, H. (1973a) Virus particles in early mouse embryos. J. natn. Cancer Inst. 51, 1041-1050.

Biczysko, W., Solter, D., Pienkowski, M. \& KopRowski, H. (1973b) Interactions of early mouse embryos with oncogenic viruses-simian virus 40 and polyoma. I. Ultrastructural studies. J. natn. Cancer Inst. 51, 1945-1954.

Chase, D.G. \& Pikó, L. (1973) Expression of A- and C-type particles in early mouse embryos. J. natn. Cancer Inst. 51, 1971-1975.

Chase, D.G., Winters, W. \& Pikó, L. (1972) Replication of human adenovirus in cultured mouse embryos. J. Cell Biol. 55, 39a, 77.

Claringbold, P.J., Biggers, J.D. \& Emmens, C.W. (1953) The angular transformation in quantal analysis. Biometrics 9, 467-484.

Enders, A.C. \& Schlafke, S.J. (1965) The fine structure of the blastocyst: some comparative studies. In Preimplantation Stages of Pregnancy, pp. 29-59. Eds G. E. W. Wolstenholme \& M. O'Connor. Churchill, London.

Gardner, R.L. \& Papaloannou, V.E. (1975) Differentiation in the trophectoderm and inner cell mass. In Early Development of Mammals, pp. 107-132. Eds M. Balls \& A. E. Wild. Cambridge University Press.

Gross, L. (1970) Oncogenic Viruses, 2nd edn, Chap. 11, pp. 446-449. Pergamon Press, London.

Gwatkin, R.B.L. (1967) Passage of Mengovirus through the zona pellucida of the mouse morula. $J$. Reprod. Fert. 13, 577-578.

GWATKIN, R.B.L. \& AUERBACH, S. (1966) Synthesis of a ribonucleic acid virus by the mammalian ovum. Nature, Lond. 209, 993-994.

Kalter, S.S., Heberling, R.L., Smith, G.C., Panigel, M., Kraemer, D.C., Helmke, R.J. \& Hellman, A. (1974a) Vertical transmission of C-type viruses: their presence in baboon follicular oocytes and tubal ova. J. natn. Cancer Inst. 54, 1173-1176.
Kalter, S.S., Panigel, M., Kraemer, D.C., Heberling, R.L., Helmke, R.J., Smith, G.C. \& Hellman, A. (1974b) C-type particles in baboon (Papio cynocephalus) preimplantation embryos. J. natn. Cancer Inst. 52, 1927-1928.

MARSK, L. \& LARSSON, K.S. (1974) A simple method for non-surgical blastocyst transfer in mice. $J$. Reprod. Fert. 37, 393-398.

Mims, C.A. (1966) Immunofluorescence study of the carrier state and mechanism of vertical transmission in lymphocytic choriomeningitis virus infection in mice. J. Path. Bact. 91, 395-402.

Mintz, B. (1962) Experimental study of the developing mammalian egg: removal of the zona pellucida. Science, N.Y. 138, 594-595.

Mohanty, S.B. \& Bachmann, P.A. (1974) Susceptibility of fertilized mouse eggs to minute virus of mice. Infect. Immun. 9, 762-763.

Neighbour, P.A. (1976) The effect of maternal cytomegalovirus infection on preimplantation development in the mouse. J. Reprod. Fert. 48, 83-89.

Neighbour, P.A. (1977) Susceptibility of the mouse preimplantation embryo to viral pathogenesis. $\mathrm{Ph} . \mathrm{D}$. thesis, University of London.

Rager-Zisman, B. \& Merigan, T.C. (1973) A useful quantitative semimicro-method for viral plaque assay. Proc. Soc. exp. Biol. Med. 142, 1174-1179.

Reubner, B.H., Miyai, K., Slusser, R.J., Wedemeyer, P. \& Medearis, D.N., JR (1964) Mouse cytomegalovirus infection. An electron microsopic study of hepatic parenchymal cells. Am. J. Path. 44, 799821.

SAWICKI, W., Baranska, W. \& Koprowski, H. (1971) Susceptibility of unfertilized and fertilized mouse eggs to simian virus 40 and Moloney sarcoma virus. J. natn. Cancer Inst. 47, 1045-1051.

SMITH, M.G. (1954) Propagation of salivary gland virus of the mouse in tissue cultures. Proc. Soc. exp. Biol. Med. 86, 435-440.

Snedecor, G.W. \& Cochran, W.G. (1967) Statistical Methods, 6th edn. Iowa State University Press, Ames.

WhitTingham, D.G. (1971) Culture of mouse ova. $J$. Reprod. Fert., Suppl. 14, 7-21.

ZeilmakeR, G.H. (1969) Transmission of mammary tumor virus by female GR mice: results of egg transplantation. Int. J. Cancer 4, 261-266.

Received 18 August 1977 